\title{
Olga Gubka
}

Dnipro, Ukraine

ORCID 0000-0001-6092-019X

\section{Varfolomii Savchuk}

Oles Honchar Dnipro National University, Ukraine

ORCID 0000-0002-6324-7567

\section{The Dnepropetrovsk Space Center: from Ballistic Missiles to International Cooperation under the Interkosmos Program}

Interkosmos - the international space research program - is multilayered; it covers a variety of aspects: political, scientific, economic, propaganda, technical, etc. In the article, the authors provide insight into technical support for the Interkosmos program carried out at the Dnepropetrovsk Space and Rocket Center. The engineering background for the conversion of the Center-developed military rocketry for use in space exploration is studied. The authors, relying on the recollections of the participants, reveal the little-known aspects of the creation of a powerful satellite development facility at the Dnepropetrovsk Space and Rocket Center. The article brings into the foreground the importance of KB Yuzhnoye's idea of developing a 'unified spacecraft', meaning a space platform where it was possible to install miscellaneous devices for pursuing a wide range of scientific issues. Using the example of Poland and India, some results obtained during launches of unmanned and manned spacecraft under the Interkosmos program are studied. The participation of the mentioned countries in the creation process of many scientific instruments for implementation of the Interkosmos program and the importance of this research and design direction are accentuated.

Keywords: Interkosmos, technical support, KB Yuzhnoye, unified spacecraft, Poland, India, scientific programs, History of Science and Technology

Słowa kluczowe: Interkosmos, wsparcie techniczne, Biuro Projektowe Jużnoje, zunifikowany statek kosmiczny, Polska, Indie, programy naukowe, historia nauki i technologii

Introduction

The purpose of the article is to analyze the conversion from military rocketry to the peaceful exploration of space at the largest military-industrial Yuzhnoye Design Bureau, its role in this process, i.e. in development of the hardware for the international program Interkosmos, the design solutions that ensured its success, and the logic of search and 
design work carried out for this project by the Yuzhnoye team. And, as a result, the output of the Interkosmos program, achieved thanks to the technology designed and developed at the Dnepropetrovsk Rocket and Space Center.

Quite a lot of research papers have been devoted to the Interkosmos international program, both in Russia and in Ukraine nowadays. It also sparks the interest of foreign science and technology historians. Their publications are quite diverse and have different goals. Some publications reflect the perception of this program by its participants. For example, an article by cosmonaut Vladimir Remek, the English translation of which is quoted in the report of the USA Publishing Data Services for Eastern Europe. ${ }^{1}$ It summarizes the main areas of cooperation between Czechoslovakia and the USSR with in the framework of this program. The authors also studied current publications which highlighted the results of space exploration as part of this international project and provided information about the research instrumentation used for the studies of space. ${ }^{2}$ Brief description of the first Soviet-Polish experiment onboard, the InterkosmosKopernik 500 satellite, is presented in a joint publication by the Polish and Soviet scientists. ${ }^{3}$ The importance of the Interkosmos program for the establishment of a solar research program from space and the participation of Poland in this program is studied in the Sylwester's article. ${ }^{4}$ His articles also provide data on the equipment created in Poland. ${ }^{5}$ The author notes that the Interkosmos program played an important role in the further development of such studies of space. Isabelle Gouarné in her article highlights the necessity and difficulties of cooperation between France and the USSR in the space field. ${ }^{6}$ She sees a positive role of Interkosmos in the facilitation of the international communication of scientists and, what is more, Interkosmos 'is the gold standard for international cooperation, and it enabled the mission programs and meeting agendas in dialogue with the French. ${ }^{7}$

For our research, the most important were the research papers focused on the issues of peaceful space exploration in the context of the research goal. Such papers were few; they rarely reflect the space engineering history of OKB-586, specialized in the development of a series of satellites for scientific research and their injection into orbit. Few people know that in parallel with the preparation of OKB-1 for the launch of the first artificial Earth satellite, OKB-586 in Dnepropetrovsk was entrusted to do a similar task for redundancy purposes. ${ }^{8}$ This can be considered a reference point for the origin of space exploration in OKB-586.

1 V. Remek, Astronaut on CSSR-USSR cooperation in Intercosmos Program, "Rude Pravo" 28 May 1982, [in:] East Europe Report. Scientific Affairs, "JPRS" 10.08.1982, no 751, p. 1-5.

2 O. Wolczek, Poland in the Intercosmos program, "Spaceflight" vol. 22, 1980, no 5, p. 190-192.

3 J. Hanasz, V.I. Aksenov, G.P. Komrakov, First results of the Soviet-Polish space experiment 'Intercosmos-Kopernik 500', [in:] Exploration of the Planetary System, Dordrecht 1974, p. 67-73, DOI 10.1007/978-94-0102206-4_7.

4 J. Sylwester, Impact of the Intercosmos Programme on the Past, Present and Future of Solar Space Research [in:] Materialy Mezhdunarodnoj nauchnoj konferencii 'Interkosmos-30', 9-10.04.2001, ed. by V.A. Kotel'nikov, Moscow 2003, p. 73-81.

5 Ibid.; idem, Experience of Wroclaw Team in Construction of Solar X-ray Instruments, [in:] ESA, vol. 493, 2001, p. 377-382.

6 I. Gouarné, Dépasser les tensions Est-Ouest pour la conquête de l'espace La coopération franco-soviétique au temps de la guerre froide,"Les Cahiers Sirice" vol. 2, 2016, no 16, p. 49-67.

7 lbid., p. 58.

8 Prizvany vremenem. Ot protivostojanija k mezhdunarodnomu sotrudnichestvu, ed. by S.N. Konjuhov, Dnepropetrovsk 2009, p. 96. 
In fact, this period (i.e. late 1950s-1960s) in the space history of OKB-586 eludes foreign researchers of the Interkosmos program. In 2016, the first book on the Interkosmos program was published abroad. ${ }^{9}$ As stated in the introduction, 'a major feature of this book is the number of personal interviews with the Interkosmos participants'. ${ }^{10}$ In this respect, the book is unique. However, it can be considered too bold an assertion that the authors in the book fully explore the premises of this program, in particular the engineering ones, that reflect, for example, the activities of OKB-586 (Yuzhnoye Design Bureau). In a short chapter titled History and development of the Interkosmos program the authors dedicate only a few paragraphs to this issue, and this, of course, is not enough to highlight the engineering activities and the role of the aforementioned Design Bureau in the Interkosmos program. The engineering work of OKB-586 (Yuzhnoye Design Bureau), its results, and functioning are presented in more detail in the monograph published in 2011.11 Up till now, this book is perhaps the most comprehensive study presenting the history of Soviet-Russian space science to the foreign (English-speaking) reader, in which the Soviet space program of uncrewed astronautics is sequentially and thoroughly reviewed.

In the general narrative about the Soviet space program - its achievements and failures - the authors of the Russian Space Probes also found a place to consider such issues as the early history of Soviet space science and its engineering and technical support. At the same time, the authors examined, in chronological order, such topics as the first Soviet Earth satellites, satellites of the MS, DS, and DS-U series, and the Interkosmos program. A critical analysis of these sections, however, reveals many inaccuracies and even errors. In particular, in the subsection Dnepropetrovsky sputnik (DS) the authors state: 'The actual designer was Vyacheslav Kovtunenko, later head of the bureau named after Yangel.'12 This information is incorrect. Kovtunenko never headed OKB-586, either before or after the death of Yangel. Other inaccuracies relate, for example, to the dates of certain events (for example, the date the R-12 combat missile was accepted for service), the names of missiles, etc. The book under consideration is aimed at revealing the history of SovietRussian space science, and the authors managed to do it very well. Yet, many of the issues that we laid out at the beginning of our article, are not considered by them. We humbly believe that the research presented in this text can fulfill some gaps in this study area.

Methodologically, in order to achieve this goal, a problem-chronological approach is crucial. It enables us to identify the problems that were decisive at each stage of OKB-586 transition from the combat missilery to peaceful space exploration, implementation of the conversion process and growth of scientific research of space, and to highlight the characteristic features of this process inside the team, focusing on engineering solutions.

For various technical reasons, the first two launches of the DS-1 satellite, in 1961, were unsuccessful. At the second launch, the satellite DS-1 fell in the region of Indonesia. ${ }^{13}$ At the third launch on 16 March 1962, the 63C1 launch vehicle ejected into the near-Earth

9 C. Burgess, B. Vis, Interkosmos: The Eastern Bloc's Early Space Program, Cham, Heidelberg 2016.

10 Ibid., p. xii.

11 B. Harvey, O. Zakutnyaya, Russian Space Probes: Scientific Discoveries and Future Missions, Dordrecht 2011.

12 Ibid., p. 67.

13 Prizvany vremenem, p. 102. 
orbit the first satellite, designed at Yuzhnoye, with the index DS (meaning 'Dnepropetrovsk Satellite'), which received the name Kosmos-1 in the TASS message.

\section{Creation and production of first-generation ballistic missiles (1957-1966)}

It all began with the military-political standoff of the two political systems - the USSR and the USA. As far back as in 1946, in the USSR Council of Ministers Decree 'On Rocket Weapons', a separate paragraph emphasized the following: 'To consider the development of rocket weapons a top priority national issue and to oblige all the ministries and organizations to carry out rocket weapons tasks as urgent. ${ }^{14}$ In the 1950s, as a result of this Decree, the actual steps were taken to match the United States in the field of strategic nuclear weapons for the sake of domestic rocket technology. Responsibility for solving this problem was initially assigned to SDB-1 (special design bureau) named after Sergey Korolev.

The USSR set a course for the development of military rocketry. In the early 1950s, the scale of the project, aimed at creating the country's missile weapons, grew so much that it went beyond the scope of one organization and one person, even as competent as Korolev. In this project, Dnepropetrovsk played an important role. Back in 1951, the Dnepropetrovsk Plant No. 586 was to launch the production of the 70 R-1 missiles developed at the Korolev Design Bureau. By 1953, the plant was supposed to produce up to 700 missiles per year. ${ }^{15}$ Since 1951, Vasiliy Budnik, one of the outstanding engineers of rocket and space technology, ${ }^{16}$ was the chief designer of the Plant No. 566 Design Bureau.

At the same time, the State military establishment demanded a new, better performing operational missile. Due to short-range and reduced efficiency, the R-1 and R-2 missiles could not be considered as strategic weapons, although they posed rather a serious threat to the American military bases, located near the borders of the USSR in Europe and Asia.

The outstanding designer, Budnik, mentioned in his memoirs that the defense officials needed an anti-jam missile that could be kept secret and at the same time maintain maximum combat readiness at launch. Hence, the proposal to use high-boiling components of fuel-nitric acid as an oxidizing agent and kerosene both as propellant and autonomous control system. ${ }^{\prime 17}$ Therefore, the scientific-based design thinking of the team, guided by Budnik, was aimed at replacing the Korolev's liquid-oxygen missiles with the missiles that would operate on high-boiling components.

On 13 February 1953, the Council of Ministers of the USSR adopted a resolution by which the design bureau of Plant No. 586, located in Dnepropetrovsk, was entrusted to develop a new medium-range military missile R-12. In order to complete this task, Budnik

14 State Archive of the Russian Federation, Postanovlenie Soveta Ministrov SSSR no 1017-419 ss ot 13 maja 1946 g. «Voprosy reaktivnogo vooruzhenija», Podlinnik. Avtograf I.V. Stalina, f. R-5446, op. 3as, d. 23, p. 216.

15 V.S. Savchuk, F.P. Sanin, V.Ja. Yacenko, M.E. Kavun, A.V. Portnov, 'Secretnij' pidrozdil galuzi, ed. by M.V. Poljakov, Dnepropetrovsk 2001, p. 21.

16 V.S. Savchuk, V.S. Budnik ta jogo naukovo-konstruktors'ka shkola, "Nauka ta naukoznavstvo" 2013, no 3, p. 89-101.

17 V.S. Budnik, Ot shturmovikov IL-2 do kosmicheskih raket (vospominanija), Dnepropetrovsk 1993, p. 24. 
addressed the government with a proposal to establish an independent experimental design bureau based on the special design bureau by the Plant. It was supposed to be engaged in the creation of the national combat missile on high-boiling (long-stored) propellants, keeping the groundwork on serial production of the missiles developed at the Korolev Design Bureau (DB). ${ }^{18}$ By the resolution of the Central Committee of the Communist Party of the Soviet Union (CC CPSU) and the Council of Ministers of the USSR, on 10 April 1954, such a design bureau was established and named SDB-586 (Special Design Bureau). It was led by Yangel, the chief designer, ${ }^{19}$ and Budnik, his first deputy. ${ }^{20}$ Nikolay Shnyakin was appointed the chief designer of the Plant No. 586, at the same time being in charge of serial production of the missiles developed at the Korolev design bureau. ${ }^{21}$ In 1966, SDB-586 was renamed into the Yuzhnoye Design Bureau (KB Yuzhnoye), and in 1991 KB Yuzhnoye was named after Yangel.

KB Yuzhnoye, located in Dnepropetrovsk, became one of the leading enterprises in the USSR to develop combat missile systems for strategic purposes, which would help to achieve parity in the missile-nuclear standoff of that time. Its activity was based on gigantic-scale multibranch cooperation between the organizations from various scientific and industrial fields, and, first of all, on the robust experimental-production base of Yuzhnyy machinebuilding plant (Yuzhmash). The design bureau found itself in the position of a leader capable of further use of the gained experience for the creation of launch vehicles and the development of spacecraft. The considerable theoretical background for training in the rocket and space field was provided by the Dnepropetrovsk State University (DSU) and the division of engineering mechanics (hereinafter the Institute of Engineering Mechanics of the National Academy of Sciences of Ukraine). In 1951, DSU established a 'secret unit' for the training of future specialists in the rocket and space industry: the Faculty of Physics and Technology. ${ }^{22}$

In 1954, the appointment of Yangel as the chief designer of SDB-586 had a significant impact on further growth of the Dnepropetrovsk Space Center. The Center itself has not only become a leader in designing strategic combat missiles but also played an important role in the conversion of the missile and space technology and development of the international program Interkosmos.

Appointment of Yangel to SDB-586 ramped up the development of the R-12 missile. Comparison of combat characteristics of the R-12 and R-5M, developed at SDB-586 and SDB-1, convinced Yangelabout the need for significant optimization of the R-12 performance and tactical properties. As a result, the R-12 was to surpass the R-5M in terms of tactical and technical characteristics:

With the promised high-degree alert of the missile, Yangel proposed: to make its flight range 2000-2100 km; introduce autonomous onboard control system instead

V.P. Gorbulin, O.Ju. Koltachihina, Ju.A. Hramov, Osnovnye periody i jetapy razvitija raketno-kosmicheskoj tehnyki Ukrainy. Ch. 2. Sozdanie boevyh strategicheskih ballisticheskih raket i raketnyh kompleksov (1957-1900), "Nauka ta naukoznavstvo" 2014, no 2 (84), p. 77. Ibid.

20 Archive of the Presidium of the NAS of Ukraine, Lichnoe delo akademika Budnika V.S., op. 646, p. I.

21 V.P. Gorbulin, O.Ju. Koltachihina, Ju.A. Hramov, op. cit., p. 77

22 V.S. Savchuk F.P. Sanin, V.Ja. Yacenko, M.E. Kavun, A.V. Portnov, 'Secretnij' pidrozd I galuz . 
of a complex system for ground-based flight path correction; use thermonuclear charge instead of nuclear one as in R-5M; use high-boiling components for fuel. By that time, the studies showed that use of high-boiling oxidizers, though leading to a decrease in specific thrust of the engine, provided several advantages, the main ones being the possibility of long-term missile storage in loaded state, without loss of fuel through evaporation, and shorter time for pre-launch processing. ${ }^{23}$

In March 1955, the R-12 new preliminary design was accomplished and approved by the Ministry of Armed Forces of the USSR and the Ministry of Defense Industry of the USSR. On 13 August 1955, Yangel was appointed the chief designer of the R-12 missile, and Budnik became his deputy. ${ }^{24}$ In August of the same year, the R-12 development began. ${ }^{25}$ The R-12 missile, manufactured at Yuzhmash, was launched on 22 June 1957, from Kapustin Yar cosmodrome in Astrakhan region. The launch was successful. Thus, in October 1958, the R-12 mass production started. The missile was accepted into service on 4 March 1959, and stayed on combat duty until 1988.

The designers of SDB-586, inspired by their first success, guided by Yangel and Kovtunenko, within the shortest possible time, developed the two new strategic missiles: $\mathrm{R}-14$ with a firing range twice as large as that of the R-12, and the intercontinental R-16. ${ }^{26}$

The R-14 missile with a maximum range of up to $4500 \mathrm{~km}$ was capable of hitting strategic targets in any areas of Europe, Asia, parts of North America, and Africa. And while the R-14 project was accepted without any reservations, a possibility of creating the R-16 missile with the declared characteristics was put into question. The SDB-1 chief designer, Korolev, considered high-boiling propellants unsuitable for the intercontinental missile. As a result, the government decided to carry out a scientific investigation of the project. The fate of a new direction depended on the results. The chairman of the expert commission, academician Mstislav Keldysh, reported to the government that, in principle, there was a possibility to create an intercontinental missile $\mathrm{R}-16,{ }^{27}$ and this resulted in the approval of the project.

In parallel with this decision, the government (apparently for redundancy purposes) instructed the Korolev design bureau (SDB-1) to create a similar oxygen-powered missile. ${ }^{28}$ Interestingly, in light of all the main characteristics, Yangel's R-16 turned out to be better than Korolev's R-9A: the country obtained real strategic combat weapons (range of the $\mathrm{R}-16$ is 13.000 kilometers; yield is up to 5 megatons). With the delivery of the R-14 and R-16 to service, the chosen direction was finally approved, and the young team of SDB586 became a recognized leader in military missiles development.

In the fall of 1958, Mitrofan Nedelin (First Commander-in-Chief of the USSR Missile Forces) decided to build two experimental silo launchers, and in June 1960, the USSR

24 Zadacha osoboi gosudarstvennoi vazhnosti. Iz istorii sozdaniia raketno-iadernogo oruzhiia $i$ Raketnykh voisk strategicheskogo naznacheniia (1945-1959 gg.): sbornik dokumentov, Moscow 2010, p. 494.

25 Ibid., p. 506.

26 S.N. Konyuhov, Uchenyj, tvorec, entuziast, "Technicheskaja mehanika" 2001, no 1, p. 182.

27 F.P. Sanin, O.A. Chaplic, V.M. Kovtunenko: period raboty v KB 'Yuzhnoe' im. M.K. Jangelja, "Visnik Dnipropetrovs'kogo universitetu. Serija Istorija i filosofija nauki i tehniki" vol. 19, 2011, no 19, p. 4.

28 V.P. Platonov, Planeta Kovtunenko, "Zerkalo nedeli" 2005, no 13, p. 13. 
State Committee on Defense Equipment issued an order 'On creation for missiles R-12, R-14 and R-16 and R-9A of silo launchers Dvina, Chusovaya, Sheksna and Desna'. ${ }^{29}$ It was the R-12 that turned out to be suitable for the silo method of deploying ground-based strategic missiles; this missile was the first one to be placed to combat duty in the silo. In order to do this, some design changes were implemented to its system, after which it became a unified R-12U.

In February 1961, the first successful launch of the R-16 missile was carried out. In July 1962 , its development tests began in silo launcher (R-16U). In the summer of 1963, the $\mathrm{R}-16 \mathrm{U}$ missile system was put into service and was on combat duty until 1976. The R-12, R-14, and R-16 missiles formed a complex of the first-generation combat ballistic missiles (1957-1966). They were suitable for both land and silo launches. The advantages of these missiles were a long-term stay on combat duty when loaded and an autonomous control system. In fact, thanks to Yangel and the SDB-586 team, the path to military missiles strategic equivalence between the USSR and the USA turned out to be open, since the R-12, R-14, and R-16 missiles had nuclear warheads.

From the archive documents: 'Creation of the R-16 missile completed the R-12, R-14, R-16 military missile complex, which enabled the creation of a new kind of troops in the country - the Strategic Missile Forces. ${ }^{\prime 30}$ One of the major gains in the development of the first-generation combat ballistic missiles was that it provided the experience that enabled transition to peaceful space exploration.

\section{Peaceful space exploration. Space rockets conversion}

The launch of the first artificial Earth satellites in 1957 initiated international cooperation in the field of exploration and use of outer space. The foundations of such international cooperation were laid by joint optical observations. ${ }^{31}$ However, the absence of relatively simple satellites which could carry the equipment necessary for a variety of experiments made systematic study and exploration of outer space difficult. Nevertheless, international cooperation in the field of outer space exploration, especially with the socialist countries, was of crucial importance for the Soviet Union in both political and scientific context. In March 1962, in Warsaw, the Agreement on inter-academy cooperation between the socialist countries ${ }^{32}$ was signed. The first meeting of the socialist countries' Science Academies representatives was held, where the issue of "Scientific research using satellite observation" was included in the plans for multilateral cooperation.' ${ }^{33}$

29 V.P. Gorbulin, O.Ju. Koltachihina, Ju.A. Hramov, op. cit., p. 78.

30 Central State Archive of Public Organizations of Ukraine, Harakteristika dejatel'nosti Juzhnogo mashinostroiteI'nogo zavoda i Konstruktorskogo bjuro «Juzhnoe» (1944-1967 gg.) ss., f.1, op. 24, d. 6340, I. 1-16.

31 «Intercosmosu - 50», "Konstruktor" 15.10.2019, no 21 (1048), p. 1.

32 O.G. Gazenko, Programma 'Interkosmos'. Kratkij istoricheskij ocherk, [in:] Materialy Mezhdunarodnoj nauchnoj konferencii 'Interkosmos-30', 9-10.04.2001, Moscow 2003, p. 15.

33 R.V. Ryhlova, Pervye opticheskie nabludenija iskusstvennyh sputnikov Zemli: kak jeto bylo, Materialy doklada, predstavlennogo 27 sentjabrya 2007 goda na yubilejnom nauchno-tehnicheskom seminare "Problemy obnaruzhenija i soprovozhdenija kosmicheskih ob'ektov v okolozemnom kosmicheskom prostranstve", Ifvn.astronomer.ru/report/0000036/ [accessed 02.02.2020] 
The large-scale studies of the near-Earth space, which began in the 1960s in the USSR, were the result of the rapid development of strategic military missilery. The first launch vehicles that opened up prospects for spacecraft for various purposes were created on the basis of military rocketry. ${ }^{34}$ The time has come to create peaceful space technology at KB Yuzhnoye.

The beginnings were not easy. In a conversation with a journalist, Vladimir Gubarev, an academician Vladimir Utkin (one of the founders of cosmonautics in the USSR) spoke about the role of the outstanding designer, Kovtunenko, in the development of this new direction: 'Undoubtedly, for KB Yuzhnoye, Vyacheslav Kovtunenko did a lot; he is the founder of the space direction, because Yangel and I still had to deal mainly with the military issues. ${ }^{\prime 35}$

At the same time, Utkin noted a rather serious denial (at first) of Kovtunenko's idea of establishing a powerful space satellite center based on a relevant design bureau. That is how Utkin explained the situation:

This is when the struggle began against that idea of his! Why didn't I like it? I believed, together with my closest circle of colleagues, that the design bureau should not be divided [...] This would weaken KB Yuzhnoye, and I could not allow this to happen [...] We had to keep all the intellectual forces together, and only then could we efficiently solve the problems that the country was facing [...] And then I thought that we could not let Kovtunenko 'go' [to design satellites - authors' note]. A huge burden of defense issues was laid on us, and if he had left, the people would have started leaving too; the 'fight' would begin - no, I couldn't allow this! ${ }^{36}$

Nevertheless, the need to develop a new direction was recognized, and the idea itself was brought to life. Although the development of strategic missiles remained the main direction of the Design Bureau's activities, YAngel, and especially Kovtunenko, initiated putting into service and converting military missiles into launch vehicles in order to launch artificial satellites.

A vivid example of this is the history of the origins of the 'firstborn' among the launch vehicles, developed at KB Yuzhnoye - 63C1 (named Kosmos), which became the first space launch vehicle based on a combat missile developed in the USSR. Under Kovtunenko's guidance, parallelly to the development of the LV 6351 (customer index 11K63), the second stage was created and then installed into the 8 K63 (R-12) single-stage combat missile, the flight tests of which started in 1961.

The idea to develop a launch vehicle based on the developed combat missiles 8K63 (R-12), 8K65 (R-14), 11K69 (R-36), and others turned out to be successful and practical. The terms and costs of the carrier development were reduced, its operation was simplified due to use of the available industrial equipment and serial components of the basic missile as well as launch complexes and their facilities. ${ }^{37}$

34 S.N. Konyuhov, V.I. Dranovskij, A.M. Popel', I.N. Lysenko, Vklad GKB 'Yuzhnoe' v realizaciju programmy 'Interkosmos', [in:] Materialy Mezhdunarodnoj nauchnoj konferencii 'Interkosmos-30', 9-10.04.2001, Moscow 2003, p. 31.

35 Vladimir Gubarev, Besedy s akademikom Vladimirom_Utkinym. Chast' poslednjaja, pravda.ru/science/909597besedy_s_akademikom_vladimirom_utkinym_chast_poslednjaja/_[accessed 02.02.2020].

36 lbid.

37 S.N. Konyuhov, V.I. Dranovskij, A.M. Popel', I.N. Lysenko, op. cit., p. 31. 
In fact, this was the first example of conversion in rocket technology. At the same time, at KB Yuzhnoye, the work was underway to make the first satellites for the new carrier. As early as 16 March 1962, the 63C1 launch vehicle (LV 63C1) placed on the near-earth orbit the first KB Yuzhnoye's satellite with index DS (Dnepropetrovsk Satellite), which was named Kosmos-1 in the Telegraph Agency of the Soviet Union (TASU) report. In the same message, TASU announced the program for conducting a wide range of space research, Kosmos, with a series of new type devices. ${ }^{38}$ This program included the study of solar radiation and activity, cosmic rays, the radiation belt, and the Earth's magnetic field, the ionosphere and the propagation of radio waves, meteoric matter, remote sensing of the atmosphere, the surface of the Earth and the World Ocean, development of spacecraft elements, components, and equipment.

We can consider that from that moment on, the 'space era' began for KB Yuzhnoye. The $63 \mathrm{C} 1$ is characterized by simple design and low manufacturing cost. The launch vehicle enabled elevating the spacecraft weighing up to $450 \mathrm{~kg}$ to an altitude of $200 \mathrm{~km}$. The work on the creation of new types of launch vehicles and spacecraft was placed on a broad footing.

\section{Unification of spacecraft at KB Yuzhnoye and the advantages it provided}

Until 1965, the activities of KB Yuzhnoye in the field of spacecraft development and production were not yet indicative of a systematic approach. That period can be described as a stage in the creation of the unique single-use spacecraft, aimed to solve field-specific tasks in space; during this period, 15 spacecraft of eight types were developed and placed into orbits. ${ }^{39}$

The launches of the first spacecraft initiated a significant expansion of space research. A considerable batch of applications was sent from the Academy of Sciences and other organizations for the creation of new satellites and equipping them accordingly. The positive results of the first launches confirmed the prospects of remote methods for solving scientific and applied problems. In order to expand the scope of the enterprise, in 1965, a spacecraft-specialized Design Bureau was created as part of KB Yuzhnoye. The first chief designer of the new SDB was Kovtunenko. Thus, in order to expand the research and design work at KB Yuzhnoye, an important organizational step was taken. The need to unify the spacecraft resulted from a many orders and a wealth of experience in developing the first national spacecraft. At the Design Bureau, the idea of creating a 'unified spacecraft', that is, a space platform, with a possibility to install miscellaneous equipment for solving a vast range of scientific issues, was realized for the first time in world history. ${ }^{40}$ The recollections of Sergey Kavelin (one of the leading developers of 
the unmanned spacecraft for the Interkosmos program) reveal the little-known details of creating the facilities and resources of the program:

Then the idea of making satellites unified was born. Kovtunenko gave trucks as an example: today, they are with truck bodies, which will be removed tomorrow and replaced with another body. The strategy to follow was found. A unified complex of service systems (telemetry, power, management) was created. In total, it accounted for approximately 85 percent of the design. The Space Research Institute developed a device to translate address commands from the unified part. After this, it would just be enough to install the equipment required to solve current problems. [...] Another difficulty that we encountered in those years was the authorship. Another - satellite launched on behalf of the Soviet Union. The question immediately arises, who is the developer? Korolev's name was known, but KB Yuzhnoye then remained strictly classified. The solution was found: a limited number of engineers were presented as employees of the DSU [Dnepropetrovsk State University - authors' note]. According to one legend, it was the University that not only developed but also manufactured the unified parts of the satellites. Probably well-informed people recognized the level of good industrial production, that is, being manufactured at a plant, but not at the University laboratories. But they turned a blind eye to it. ${ }^{41}$

The benefits of unification were obvious. It served a variety of scientific purposes: use of the same body, composition of service systems, onboard equipment control circuit, power supply system, and antenna feeder devices. In addition, it was possible to organize serial production of the satellites and their components, use a single test base, and thus significantly reduce the cost of spacecraft manufacturing and space research. ${ }^{42}$

Considering the contribution of KB Yuzhnoye to the Interkosmos program, the authors of the article have noted that from the very beginning, the research and design team encountered complexity of research problems. Therefore, constructing a universal satellite was not merely problematic, but hardly possible. At the same time, in the authors' opinion, 'a number of specific features enabled the creation of a whole series of satellite modifications which would help to solve some homogeneous or at least similar-nature research problems. When switching from one modification to another, the maximum continuity of the design is maintained. As for the support facilities and onboard equipment control circuits, they practically do not depend on the specific scientific problem solved by the satellite. ${ }^{43}$ One of the veterans of the rocket and space industry, Professor Fedor Sanin, thus recalled this design effort:

The so-called 'unified satellite' was created at the design bureau, led by Kovtunenko, and made possible to carry out space research for any customer, from the Academy of Sciences and the military to forestry and agriculture. The satellite is equipped with a universal control system and telemetry. The unification was based on the independence of the complex support systems, of apparatus design and onboard

41 «Vas zhdut na Orbite!», "Konstruktor" 14. 11. 2019, no 23 (1050), p. 2-3.

42 S.N. Konyuhov, V.I. Dranovskij, A.M. Popel', I.N. Lysenko, op. cit., p. 31-32.

43 Ibid. 
equipment control circuit, from a specific scientific problem that was solved. That is why many Soviet and foreign customers cooperated willingly with KB Yuzhnoye. The launches were inexpensive, since the launch vehicles were also based on ready-made combat missiles, and the satellites had universal control and telemetry systems. The customer country or other organizations only assigned their names, such as 'Oreol', 'Bhaskara', 'Okean', 'Sich', and others. It should be noted that many did not believe in the creation of unified satellite systems, and the Ministry also objected. But it was a brilliant decision. ${ }^{44}$

By 1963, several modifications of the unified satellites were proposed:

- DS-U1: non-oriented, with a chemical source of electric energy;

- DS-U2: non-oriented, on solar energy;

- DS-U3: uniaxially oriented (to the Sun), on solar energy. ${ }^{45}$

The modifications of the DS-U3 satellite had an additional subsystem of orientation and stabilization calming for pointing the satellite's longitudinal axis at the Sun and scanning the solar disk. The design of the unified satellite, in addition to the main service systems, provided a possibility to install, if necessary, additional support systems (orientation by the Earth's magnetic field, spin, etc.), which expanded the satellite application field. ${ }^{46}$ Each modification of the DS series satellite was specific and designed for particular, in-depth scientific experiments.

The development of a series of unified satellites helped Yuzhmash to solve the problem of serial production organizing. As a result, the Academy of Sciences has significantly expanded the range of fundamental, scientific, and applied research in near-Earth space.

Various configurations of the unified satellites DS-U1, DS-U2, and DS-U3 were being launched for 11 years. The launches of 44 spacecraft of thirty-one (31) modifications are another confirmation that the chosen path was right. The headship of KB Yuzhnoye in the field of creating of the world's first unified satellites is confirmed by the copyright certificate No. 45372 with a priority of 3 June $1967 .{ }^{47}$

The next step in the development of this direction at Yuzhnoye was the creation of the new types of unified spacecraft (such as automatic universal orbital station - AUOS), several types of defense spacecraft, as well as the series that later became known as Okean. The unified satellites type DS-U were in demand for the International Cooperation Program (1967) and were selected as the basic ones. The successful study of the nearEarth space using the Yuzhnoye-developed spacecraft together with their comparative cheapness contributed to this decision.

The first comprehensive experiment within the International Cooperation Program was the launch of a DS-U2 series satellite (DS-U2-GK Geophysical complex) in 1968 to study the upper atmosphere of the Earth and the nature of aurora polaris. This launch was assigned, in all respects, to the Interkosmos satellites category and, later on, such

44 F.P. Sanin, O.A. Chaplic, V.M. Kovtunenko - vydajushhijsja uchenyj, p. 224.

45 Rakety i kosmicheskie apparaty Konstruktorskogo bureo «Yuzhnoe», ed. by. S.N. Konjuhov, $3^{\text {rd }}$ ed., Kiev 2004, p. 108; A.V. Degtiarev, op. cit., p. 62-64.

46 Rakety i kosmicheskie apparaty, p. 151-156.

47 S.N. Konyuhov, V.I. Dranovskij, A.M. Popel', I.N. Lysenko, op. cit., p. 32. 
effort was taken repeatedly using the upgraded spacecraft Kosmos-348. The research institutes and observatories from Bulgaria, Hungary, the German Democratic Republic, Poland, Romania, Czechoslovakia, and the Soviet Union took part in this experiment. ${ }^{48}$

\section{Interkosmos program participants and its characteristics}

Space research has undoubtedly contributed to the growth of cooperation between many countries. These studies are one of the most important issues for all humanity, requiring a global investigation of phenomena and a complex approach. ${ }^{49}$ Despite various political motives that were underlying these studies, they greatly contributed both to the cooperation between the scientists from different countries and to solving many difficult scientific problems.

The Soviet Union was the first among the space-faring countries to enter the path of international cooperation..$^{50}$ On 14 April 1965, Chairman of the Council of Ministers of the USSR, Alexey Kosygin, sent a letter to the heads of governments of the socialist countries. In this letter, he proposed to discuss appropriate steps aimed at uniting the efforts in the field of the exploration and use of outer space for peaceful purposes, taking into account the scientific and technical capabilities and resources of individual countries. ${ }^{51}$ The letter emphasized that the Soviet government considered it useful to study the possibilities for cooperation between the socialist countries in such vital fields as space physics, biology and medicine, establishing long-range radio links and television, studies of the upper atmosphere and outer space using meteorological and geophysical rockets and artificial Earth satellites.52

In 1966, the Council for International Cooperation for the Exlopration of the Cosmos (abbreviated as INTERKOSMOS) was created at the Academy of Sciences of the Soviet Union. Academician Boris Petrov, member of the Presidium of the USSR Academy of Sciences, was approved as its chairman. Kovtunenko became a member of the Council and the first general director of the Interkosmos international program.

The same year (on 19 December 1966), the United Nations Organization adopted the Treaty on Principles Governing the Activities of States in the Exploration and Use of Outer Space, including the Moon and Other Celestial Bodies. The first to sign the Treaty on 27 January 1967 were the USSR, the USA, and Great Britain. ${ }^{53}$ The agreement entered into force on 10 October 1967, and became the legal foundation for such studies, including those within the framework of the Interkosmos program.

The next, perhaps the most important step in preparation for the Interkosmos program was the meeting of experts: representatives of nine socialist countries on exploration and

48 «Intercosmosu-50», p. 1.

49 O.A. Chaplic, F.P. Sanin, Programma «Interkosmos» i ee vklad v razvitie mirovoj kosmonavtiki, „Visnik Dnipropetrovs'kogo universitetu. Serija Istorija i filosofija nauki i tehniki" vol. 18, 2010, no 18, p. 65.

50 lbid.

51 Materialy soveshhanija jexpertov-predstavitelej socialisticheskih stran po issledovaniju i ispol'zovaniju kosmicheskogo prostranstva $v$ mirnyh celjah, Moscow 1967.

52 Ibid.

53 Dogovor o principah dejatel'nosti gosudarstv po issledovaniju i ispol'zovaniju kosmicheskogo prostranstva, vkljuchaja Lunu I drugie nebesnye tela, [in:] Dogovory i principy Organizacii Ob'edinennyh Nacij, kasajushhiesja kosmicheskogo prostranstva, sootvetstvujushhie rezolucii General'noj Assamblei i drugie document, Vienna 2013, p. 3-8. 
use of outer space for peaceful purposes, which was held in Moscow from 5 to 13 April 1967. ${ }^{54}$ At the meeting, each country was represented by the heads of delegations. The USSR was represented by the president of the USSR Academy of Sciences, Keldysh, the Polish People's Republic - by the Chairman of the Space Commission of the Polish Academy of Sciences, corresponding member of the Polish Academy of Sciences, Stefan Piotrowski. ${ }^{55}$

On 13 April 1967, a Program for joint work in the field of peaceful exploration and use of outer space was adopted. This date is considered the beginning

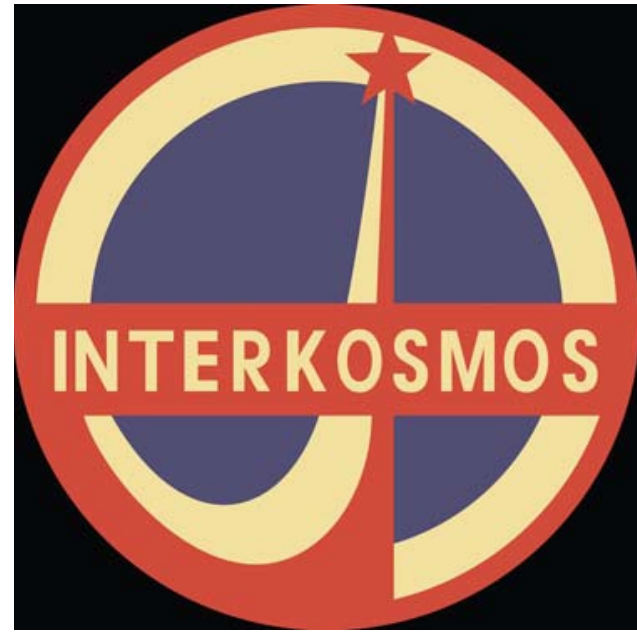

Fig. 1. Interkosmos logo (source: alchetron.com/ Interkosmos\#-jpg [accessed 27.01.2020]. of the practical implementation of the Interkosmos program, which received its official name in $1970 . .^{56}$ Practical activities of the Dnepropetrovsk KB Yuzhnoye were carried out in collaboration with the Interkosmos Council. Thus, Ukraine and Yuzhnoye, which initiated the development of international cooperation in the sphere of space exploration, were actively involved in the work at the international level.

The initiative of Yuzhnoye was to propose the use of their small-size unified spacecraft of DS-U series (1965), and later, in 1976, an automatic universal orbital station (AUOS) for conducting joint scientific experiments. The initiative was approved. Thanks to this, the USSR Academy of Sciences, in collaboration with the Academies of Sciences of the socialist countries, and later with the participation of scientific organizations of other countries, were able to implement the Interkosmos large-scale integrated space research program. In each of the nine countries participating in the program: Poland, Czechoslovakia, Bulgaria, Hungary, Romania, Mongolia, Cuba, East Germany, and the USSR, the coordinating body was organized; it was responsible for the holistic implementation of the cooperation goals. In 1979, Vietnam joined the list of participants. The Interkosmos program was identified with an emblem shown in Fig. 1. Flights with representatives of each socialist country had their individual emblems. An understandable political context was added to the design of each emblem and emphasized by certain symbols.

The Interkosmos program had an open status. For practical implementation of the planned work, initially (i.e. in 1967), four permanent working groups (PWGs) were formed: on space physics, space meteorology, space communications, and space biology and medicine. Later, in 1975, upon general agreement, a working group on remote sensing of the Earth from space was added. ${ }^{57}$ 
The conditions were such that all Soviet equipment, which was state-of-the-art in those days, was provided free of charge to the countries participating in the Interkosmos program. The equipment included spacecraft and launch vehicles, cosmodrome facilities, and a flight control center - everything that the Soviet Union had at its disposal for space navigation. Each country, in turn, offered its own research program, participated in the programs of interest and equipment development. The results of joint achievements became common property.

The international cooperation in experiments on biosatellites had an unusual arrangement. The work on the Interkosmos program began in cooperation with Bulgaria, Hungary, East Germany, Poland, Romania, and Czechoslovakia. The Interkosmos Council made it possible to attract to research on biosatellites the well-established research teams with good experimental capabilities and funding. ${ }^{58}$ The work was carried out on a nonmonetary basis. However, all parties undoubtedly benefited from the existing cooperation. Participants from the socialist countries gratuitously received the unique material, namely biosatellite-exposed animal organs and tissues, and Soviet scientists received the results of the processed material. Eventually, the United States, France, the European Space Agency, and Canada joined this cooperation.

\section{Contribution of the Dnepropetrovsk Space Center to the Interkosmos program}

The spacecraft, developed at Yuzhnoye Design Bureau became the first spacecraft in the world to carry out scientific research of the near-Earth space as part of the Interkosmos program ${ }^{59}$. On 14 October 1969, spacecraft DS-U3-IK-1 was put into orbit; in public media it was nick-named Interkosmos-1. The launch was carried out by the Dnepropetrovsk carrier Kosmos-1 (LV 11K63) at Kapustin Yar cosmodrome in the presence of scientists from nine foreign countries. ${ }^{60}$

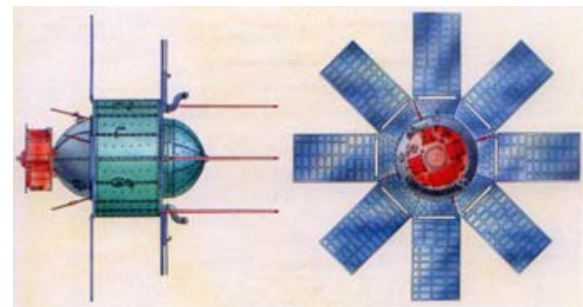

Fig. 2. Space device DS-U3-IK-1 Interkosmos-1 (source: Rakety $i$ kosmicheskie apparaty Konstruktorskogo bureo "Yuzhnoe», ed. by S.N. Konjuhov, $2^{\text {nd }}$ ed., Dnepropetrovsk 2004).

According to the statistics, '22 out of 25 automatic satellites put into orbit by the USSR within the Interkosmos program were designed at Yuzhnoye and manufactured by the Yuzhmash production association'. ${ }^{61}$ The team of the spacecraft Design Bureau (DB-3) led by Kovtunenko, Stanislav Konyukhov, and Vladimir Dranovsky carried out the construction of spacecraft and their control in orbit. International cooperation, initiated

L.V. Serova, 'Interkosmos' v eksperimentah na biosputnikah, "Kosmicheskij al'manah" 2001, no 5, epizodsspace.narod.ru/bibl/akiem/5-inter.html_[accessed 29.01.2020].

59 Rakety i kosmicheskie apparaty, p. 108.

60 L.A. Vedeshin, K 50-letiju poleta sputnika 'INTERKOSMOS-1', "Issledovanie Zemli iz Kosmosa" 2019, no 4, p. 87-93; L.A. Vedeshin, M.G. Kroshkin, Sputnik 'Interkosmos-1' i ego nauchnaja programma (sotrudnichestvo uchenyh socialisticheskih stran v issledovanii kosmosa, "Vestnik Akademii nauk SSSR" 1969, no 12, p. 19-27; Rakety i kosmicheskie apparaty, p. 139.

61 Ibid., p. 193. 
by Kovtunenko, expanded year after year - France, India, Sweden, Austria, and other countries became 'the space partners' of Yuzhnoye. ${ }^{62}$

By the early 1970s, the study of the interaction between the mechanisms of individual physical phenomena in near space with solar-terrestrial correlations became a fact. The DS-U type satellites were no longer suitable for solving such a complex task due to limited resources and functional capabilities. After the design studies, carried out jointly with the Institutes of the USSR Academy of Sciences, it was concluded that the two modifications of the automatic universal orbital station (AUOS) - oriented to the Earth (AUOS-Z) and to the Sun (AUOS-SM) - could almost completely satisfy the needs of fundamental studies of outer space. The mentioned stations became the basic platforms for the creation of the targeted research satellites, by equipping them with respective onboard systems of research equipment.

In total, 16 spacecraft based on the unified DS-U were launched under the Interkosmos program, including 14 spacecraft with the same name - Interkosmos, and 2 satellites: Oreol-1and Oreol-2 within the joint Soviet-French Arcade program. ${ }^{63}$ Based on AUOS-Z station, eight satellites were manufactured and launched (Interkosmos-15, Interkosmos-17, Interkosmos-18, Interkosmos-19, Interkosmos-20, Interkosmos-21, Interkosmos-24, Interkosmos-25) and Oreol-3.

The first launch of AUOS-Z was successfully carried out in 1976 (Interkosmos-15), and facilitated the implementation of the Soviet-French Arcad-3 project in 1981. The Oreol-3 satellite was a continuation of bilateral cooperation. For the first time, a series of measures were taken to eliminate the impact of electric and electromagnetic fields on the operation of research equipment. The achieved results, as well as the overall technical level of the satellites, were highly praised by specialists from many countries. Similar work was continued while preparing for launches of research equipment complexes as part of the international projects Active, Apex and Coronas-F. A lot of scientific papers contained the results of research, conducted using the Oreol-3 satellite in 1981-1987, and a special meeting of the International Congress of Geophysicists was held. In 1986, ${ }^{64}$ this work was awarded the USSR State Prize.

Experts of academic institutes assisted the Yuzhnoye specialists in resolving issues under the Interkosmos program. A unique role belongs to the Space Research Institute (SRI) in Moscow. The SRI management (Petrov, Sagdeev, Tamkovich, Narimanov) from the very beginning took the lead in the organization of work within the framework of the Interkosmos program. The SRI created an integrated test bench for development, coordination, and testing of research equipment of all spacecraft of the Interkosmos program. 'Solidarity, efficiency, simplicity, and trust that we met at SRI activated new, previously unknown forms of cooperation, defined by the word "Interkosmos". History did not know cooperation so close and honest' - the authors noted. ${ }^{65}$

62 O.A. Chaplic, F.P. Sanin, Programma «Interkosmos», p. 67.

63 S.N. Konyuhov, V.I. Dranovskij, A.M. Popel', I.N. Lysenko, op. cit., p. 32.

64 B.N. Petrov, Programma 'Interkosmos'. Sotrudnichestvo socialistycheskih stran, scifiart.narod.ru/Albums/4_004. htm [accessed 17.01.2020].

65 S.N. Konyuhov, V.I. Dranovskij, A.M. Popel', I.N. Lysenko, op. cit., p. 33. 
Flights of international crews became a qualitatively new stage of cooperation in space. In 1976, the Soviet Union proposed the participation of people from socialist countries in international space missions. On 13 July 1976, the representatives of Bulgaria, Hungary, East Germany, Cuba, Mongolia, Poland, Romania, Czechoslovakia, and the USSR signed an intergovernmental Agreement on Cooperation in the Exploration and Use of Outer Space for Peaceful Purposes. ${ }^{66}$ At the same time, the Soviet Union took the initiative to develop the Interkosmos program, which facilitated the participation of these countries in manned flights on Soviet spaceships and provided the orbital station together with the Soviet cosmonauts. This proposal was immediately supported and approved by the participating countries. At an intergovernmental meeting on 14 September 1976, it was decided to conduct these flights in the years 1978-1983. ${ }^{67}$

The first three flights were reserved for the representatives of Czechoslovakia, Poland, and East Germany. From the very beginning, these countries participated in the development of equipment and experiments for the Interkosmos series satellites, and could reasonably quickly prepare research programs for their cosmonauts. After reaching an agreement on practical issues of flight organization, the selection of candidates for cosmonauts from these three countries began immediately. The remaining flights of the Interkosmos cosmonauts were to be carried out in alphabetical order - by the names of the governments in the Russian language. ${ }^{68}$

After the consultations in the fall of 1976, the first group of candidates for cosmonauts from the socialist countries - Czechoslovakia, East Germany, and Poland (two representatives per country) - arrived at the Yuri Gagarin Cosmonaut Training Center (CTC) within the Interkosmos program. They started their training by learning Russian and the basics of space technology. In 1978, the second group of candidates for cosmonauts from Bulgaria, Hungary, Cuba, Mongolia, and Romania appeared at the CTC. The group consisted mainly of the pilots trained at military academies or military flight schools of the USSR. ${ }^{69}$

On 22 March 1978, the first international crew of Interkosmos, the Soviet cosmonaut Alexei Gubarev and his Czechoslovak counterpart Vladimir Remek, flew aboard the Salyut station. Soviet cosmonauts, Georgy Grechko and Yuri Romanenko, met the new participants at the station during their long voyage. The flight duration was 7 days, 22 hours, and 17 minutes. Many technological and biomedical experiments and studies, prepared by the scientists and specialists of the USSR and Czechoslovakia, were performed by the crew; the entire flight program was fully accomplished. In the flight relay race of the Interkosmos program, each crew passed all what was best on to the successors: traditions, accumulated data, and experience. ${ }^{70}$

66 O programme 'Interkosmos', www.astronaut.ru/as_interk/as_interk.htm_[accessed 01.02.2020].

67 O.A. Chaplic, F.P. Sanin, Programma «Interkosmos», p. 68

68 Ibid.

69 P. I. Klimuk, 'Interkosmos' kak vazhnoe zveno razvitija mezhdunarodnogo sotrudnichestva $v$ pilotiruemoj kosmonavtike, [in:] Materialy Mezhdunarodnoj nauchnoj konferencii 'Interkosmos-30', 9-10.04.2001, Moscow 2003, p. 48-51.

70 B.N. Petrov, Mezhdunarodnoe sotrudnichestvo v osvoenii kosmosa, scifiart.narod.ru/Albums/4_004.htm [accessed 02.02.2020]. 
Of course, cosmonaut flights of the countries participating in the project have become the pinnacle of the Interkosmos program implementation. For the first time, an international crew was launched into space; for the first time, a cosmonaut was not a citizen of the USSR or the USA, but a representative of a third country. Later, the cosmonauts of all countries, participating in the Interkosmos international space program, took part in orbital flights. In total, 18 expeditions visited the Salyut- 6 station, nine of which under the Interkosmos program included cosmonauts from Czechoslovakia, Poland, East Germany, Bulgaria, Hungary, Cuba, Mongolia, Vietnam, and Romania. ${ }^{71}$ Flights to the Salyut- 6 station ended in 1981, but five more cosmonauts from other countries flew into space to the Salyut-7 station, and later to the Mir station within the Interkosmos program. Thus, the joint manned space flights allowed fourteen 'non-Soviet' cosmonauts to participate in Soyuz space flights in the period from 1978 to $1988 .{ }^{72}$

As a result of the Interkosmos program, the two main areas of its activity formed: 1. conducting multipurpose scientific experiments on space exploration based on launches of unmanned spacecraft with the active participation of space partners from many countries, 2 . implementing a series of flights of cosmonauts from the member countries, involving multipurpose scientific experiments carried out by flight participants. The study of the development of these two areas with the examples of participation of Poland and India in the Interkosmos program will follow.

\section{Soviet-Polish cooperation}

Among the Interkosmos program participants, Poland was one of the most scientifically and technically developed countries. The participant countries were developing relevant research equipment both for satellites and manned spacecraft. This was especially evident when launching such spacecraft as Interkosmos-9 (Kopernik-500) and during the work of the Soviet-Polish crew at the Salyut-6 orbital station.

The launch of the unmanned spacecraft, Interkosmos-9, was carried out on 19 April 1973 and celebrated the $500^{\text {th }}$ anniversary of the birth of the great Polish astronomer Nicholas Copernicus. It was a construction of the DS-U2-IK-8 type - a modification of the unified satellite with solar power sources, developed at Yuzhnoye. For this satellite (DS-U2 type), solar panels were made not flat, but omnidirectional, installed throughout the case (alike in Luna-3). The research equipment of the satellite was manufactured in the USSR, Poland, and Czechoslovakia. ${ }^{73}$

The mass of the satellite was $256 \mathrm{~kg}$; the mass of the payload was $15 \mathrm{~kg}$. It was active until 15 October 1973. The purpose of the spacecraft launch was to study storm radiation of the Sun and the characteristics of the Earth's ionosphere.

The schedule of the mission included scientific experiments in which the USSR, Poland, and Czechoslovakia took part. On the Polish side, the Astrophysics Laboratory (Toruń), the Nicolaus Copernicus University (Toruń), the Institute of Aviation, Institute of Mathematical 


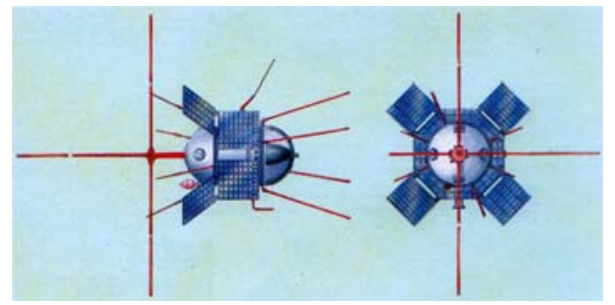

Fig. 3. Spacecraft DS-U2-IK-8 InterkosmosKopernik-500 (source: Rakety i kosmicheskie apparaty Konstruktorskogo bureo "Yuzhnoe», ed. by S.N. Konjuhov, $2^{\text {nd }}$ ed., Dnepropetrovsk 2004).

Machines, and Space Research Centre (Warsaw) actively participated in the preparation of the program of the scientific experiments. $^{74}$

The scientific research results of the Kopernik-500 spacecraftflightwerenumerous and diverse: data on storm radiation of the Sun, characteristics of the Earth's ionosphere and radio noise of ionospheric plasma, study of irregular structure of storm radiation bursts in the frequency range 3-6 MHz, study of electron concentration of the ionosphere and its irregularities, detection of a new type of radio noise in the ionosphere, etc. ${ }^{75}$ This spacecraft also brought to space the first Polish instruments for measuring solar radiation, such as RS-500K radio spectrograph to study burst radiation and parameters of the ionosphere. It was created at the Nicolaus Copernicus University and became the first Polish device to operate in orbit. President of the Polish Academy of Sciences, Witold Nowacki, noted in 1978:

Poland also designed probes for the rocket and meteorological system, developed under the Interkosmos program. The astronomical observatory of the Polish Academy of Sciences in Borowiec near Poznań, equipped with a laser rangefinder, participates in observations and measurements of the orbits of the Soviet artificial satellites. Since 1974, a terrestrial relay radio station has been operating in Poland, working in conjunction with the Soviet communication satellites Molniya. ${ }^{76}$

The Interkosmos program also influenced the development of the Earth remote sensing program in Poland. Since 1980, this program within the framework of the Interkosmos program was headed by Bogdan Ney, Corresponding Member of the Polish Academy of Sciences. He, as an active participant in the works of the Work Group on Remote Sensing (WGRS), evaluated the impact of the Interkosmos program on the development of remote sensing of the Earth in Poland:

Participation in the activities of the Interkosmos WGRS facilitated our access to space images of the Earth, and we were receiving these materials due to scientific cooperation, and not on commercial terms. As we all remember, in the summer of 1978, our famous countryman, today General-Cosmonaut Mirosław Hermaszewski, made a space flight. Remote sensing experiments, performed by Hermaszewski during the flight, were agreed with our Institute. The results of observations and satellite images obtained during this flight, in which cosmonaut General Klimuk also participated, were processed and annotated by the Center for Processing Aerial

74 Rakety i kosmicheskie apparaty, p. 136; V.A. Alekseev, A.A. Eremenko, A.V. Tkachev, Kosmicheskoe sodruzhestvo: hronika mezhdunarodnyh poletoved, ed. by A.S. Eliseev, Moscow 1987, p. 51-61.

75 Kocmicheskij apparat Interkosmos-9 (Kopernik-500), stp.cosmos.ru/index.php?id=1163\&tx_ttnews\%5Btt_new $s \% 5 D=2979 \& c H a s h=a c 034 c f a 43653 e 86 e f c 227 b 7 d 2 a 060 a c$ [accessed 29.01.2020].

76 W.S. Nowacki, S emblemoj Interkosmosa, "Pravda" 29.06.1978. 
and Space Imagery. Thanks to the cooperation within WGRS, we also received many other space images of the Earth, which significantly replenished the space materials database, which the Soviet government provided to the Polish side. ${ }^{77}$

The flight of the Polish cosmonaut was the continuation of the Soviet-Polish cooperation within the Interkosmos program. Of the 14 people initially selected for further preparation for the flight, two officers remained for the preflight stage: Hermaszewski and Zenon Jankowski. On 15 June 1978, the Soyuz-29 spacecraft was launched into space (with pilotscosmonauts Kovalenko and Ivanchenkov). After the docking (16 June 1978) of the spacecraft at the Salyut orbital station, the cosmonauts went aboard the station. The manned research complex Salyut-6 - Soyuz-29 began to function. On 27 June 1978, the Soyuz-30 was launched from the Earth, with Pyotr Klimuk and Mirosław Hermaszewski onboard. ${ }^{78}$

After the docking and transfer of the cosmonauts aboard the Salyut- 6 station, on 29 June they began to carry out research. The flight research program was completed and took into account the interests of both Soviet and Polish researchers. Table 1 lists the experimental programs (following the subject area) carried out by the Soviet-Polish crew.

Hermaszewski spent 7 days, 22 hours, 2 minutes, and 59 seconds as a cosmonaut-researcher on Soyuz-30 spacecraft and Salyut-6 orbital station (27 June-5 July 1978).

During the second international flight (of the Soviet-Polish crew) on the Soyuz-30 manned spacecraft within the Interkosmos program, scientific experiments and studies were performed at the Salyut- 6 station for both the Polish Academy of Sciences and the USSR Academy of Sciences. The most interesting and painstaking of these endeavours was the cultivation of semiconductor crystals in space, which at that time was called a revolutionary breakthrough in the field of semiconductor technology. The team members managed to collect much material on the human body tolerance of space flight conditions, e.g. the nature of changes in the cardiovascular system, etc. Based on the data obtained, effective means for preventing and maintaining high performance of cosmonauts at all stages of flight were developed; conceptual requirements for preflight crew training and proactive compensation of the effects of space flight factors on the human body were formulated. Subsequently, a whole scientific school in this area grew up at the Yuri Gagarin CTC. ${ }^{79}$

Later in his article, Professor Robert Gałązka, presenting 'extensive fragments' of the report of the Chairman of the Committee for Space and Satellite Research of the Polish Academy of Sciences at the LXXX session of the General Meeting of the Academy of Sciences on 10 December 1993, noted:

This program, despite various restrictions, allowed us to create a research and development entity and to train personnel. In terms of research, Polish teams participated in several space missions of Soviet objects. The Kopernik-500 satellite (Interkosmos-9), launched in 1973 in accordance with the project and equipment, mainly manufactured in Poland, deserves our attention. [...] In total, until 1992,

77 B. Ney, Vliyanie programmy 'Interkosmos' na razvitije distancionnogo zondirovanija Zemli v Pol'she, [in:] Materialy Mezhdunarodnoj nauchnoj konferencii 'Interkosmos-30', 9-10.04.2001, Moscow 2003, p. 45.

78 V.A. Alekseev, A.A. Eremenko, A.V. Tkachev, op. cit.

79 P.I. Klimuk, op. cit., p. 48. 
49 pieces of Polish equipment for physical experiments were launched aboard rockets and space probes. The space flight of Mirosław Hermaszewski, despite excessive propaganda, had impressive scientific content It was the first experiment on crystallization under microgravity conditions conducted by a Polish researcher. ${ }^{80}$

The characteristic feature of the Interkosmos program was involving not only the countries of the socialist bloc but also some developing countries, India in particular. Undoubtedly, in this way, the USSR also resolved a number of national strategic political issues. But this, nevertheless, did not lessen the role of Interkosmos in the establishment of space research in these countries. Especially in India, which has become one of the leading space powers.

Table 1. Experimental programs of the Soviet-Polish crew

\begin{tabular}{|c|c|c|c|}
\hline No & Date & $\begin{array}{l}\text { Name } \\
\text { of the research expe- } \\
\text { riment }\end{array}$ & Purpose \\
\hline \multirow[t]{3}{*}{1} & \multirow[t]{3}{*}{ 29.06.1978 } & $\begin{array}{l}\text { Comprehensive exa- } \\
\text { mination of the blood } \\
\text { circulatory system }\end{array}$ & $\begin{array}{l}\text { Characteristics of blood distribution in the body and } \\
\text { state of cardiac activity }\end{array}$ \\
\hline & & 'Oxygen' & $\begin{array}{l}\text { Dynamics of oxygen supply directly to body tissues; } \\
\text { its use by tissue enzymes }\end{array}$ \\
\hline & & 'Siren' & $\begin{array}{l}\text { Study of the process of directed crystallization; } \\
\text { obtaining crystals from the liquid phase }\end{array}$ \\
\hline \multirow[t]{2}{*}{2} & \multirow[t]{2}{*}{30.06 .1978} & 'Cardiolider' & $\begin{array}{l}\text { Reactions of the cardiovascular system to } \\
\text { the simulated effects of hydrostatic pressure; } \\
\text { optimization of physical load on cosmonauts }\end{array}$ \\
\hline & & 'Survey' & $\begin{array}{l}\text { Study of individual characteristics of a person's } \\
\text { mental adaptation to environmental factors }\end{array}$ \\
\hline \multirow[t]{7}{*}{3} & \multirow[t]{7}{*}{01.07 .1978} & 'Cardiolider' & Continuation of the experiment \\
\hline & & 'Heat Exchange-2' & $\begin{array}{l}\text { Study of characteristics of heat transfer between } \\
\text { the human body and its environment in space flight }\end{array}$ \\
\hline & & 'Oxygen' & Continuation of the experiment \\
\hline & & 'Taste' & Studying the causes of taste sensations disorder \\
\hline & & 'Leisure' & $\begin{array}{l}\text { Study of the influence of specifically prepared } \\
\text { television programs on the performance of cosmonauts }\end{array}$ \\
\hline & & 'Siren' & Continuation of the experiment \\
\hline & & Medical experiment & Study of metabolism by biological indicators of blood \\
\hline 4 & 02.07.1978 & 'Earth' & Remote sensing of the Earth \\
\hline \multirow[t]{2}{*}{5} & \multirow[t]{2}{*}{ 03.07.1978 } & 'Earth' & Continuation of the experiment \\
\hline & & 'Siren' & Continuation of the experiment \\
\hline \multirow[t]{2}{*}{6} & \multirow[t]{2}{*}{ 04.07.1978 } & 'Siren' & Continuation of the experiment \\
\hline & & & $\begin{array}{l}\text { Preparation of materials of scientific and biomedical } \\
\text { research and experiments for shipment to Earth }\end{array}$ \\
\hline
\end{tabular}

Compiled by the authors from the sources. ${ }^{81}$

80 R. Gałązka, Trzydzieści sześć lat działaności człowieka w Kosmosie, “Urania” vol. 65, 1994, no 1, p. 5.

81 C. Burgess, B. Vis, op. cit.; A. Alekseev, A.A. Eremenko, A.V. Tkachev, op. cit.; V. I. Kozyrev, S.A. Nikitin, Polety po programme 'Interkosmos', Moscow 1980. 
India is a country that started to create its own space industry immediately after gaining independence in 1947. Its space policy was based on a number of fundamental principles: creation of a national program for the rocket and space industry, active cooperation with foreign space and rocket countries, extensive participation in international scientific programs, etc.

The cooperation of India with the USSR in the space industry can be traced back to the early 1960s. In 1962, with the assistance of the Soviet Union, an international training ground for launching geophysical rockets was built in Thumbe (India). In particular, the Soviet meteorological rockets M-100 with Soviet and Indian-made equipment were launched from this training ground. In 1971, India adopted the first (ten-year) program for the development of the rocket and space industry, which included the construction of the first Indian satellite.

The work on the creation of the first Indian satellite reached the level of international relations, when:

on 10 May 1972, the USSR Academy of Sciences and the Indian Space Research Organization of the Government of India (ISRO) signed a special Agreement for the provision of advisory and technical assistance to the Indian side in creating a scientific spacecraft and its launch onboard a Soviet launch vehicle from the territory of the USSR. ${ }^{82}$

Implementation of this project was entrusted to KB Yuzhnoye, which, as the main developer of the launch vehicle and small-size spacecraft of the Kosmos and Interkosmos series, made a significant contribution to the design of the first Indian satellite, creation of efficient satellite design systems, satellite pre-launch preparation, etc. Yuzhnoye enabled: consulting assistance in design selection, coordination with the launch vehicle, participation in experimental ground testing, preparation of operational documentation, flight design tests at the cosmodrome, and the initial phase of spacecraft control in orbit.

In close cooperation with related enterprises, the Indian spacecraft was equipped with a gas-jet spin system, solar arrays and storage batteries, an onboard tape recorder for recording information from scientific and support equipment, and thermal coatings. ${ }^{83}$

On 19 April 1975, the Interkosmos launch vehicle (11K65M) launched into space the first Indian spacecraft, Aryabhata, from the Kapustin Yar cosmodrome. The mass of the satellite was $358 \mathrm{~kg}$. After the launch of the first Indian spacecraft in the same year, another agreement was signed between the USSR Academy of Sciences and the Indian Space Research Organization to launch next Indian satellites. The implementation of this agreement ended with the launch of the Indian satellites Bhaskara-I (7 June 1979) and Bhaskara-II (20 November, 1981) with the Soviet carriers Interkosmos from the Kapustin Yar cosmodrome. Although the "Bhaskara-I satellite retained the essential structural characteristics of the Aryabhata satellite, it was $86 \mathrm{~kg}$ heavier. 


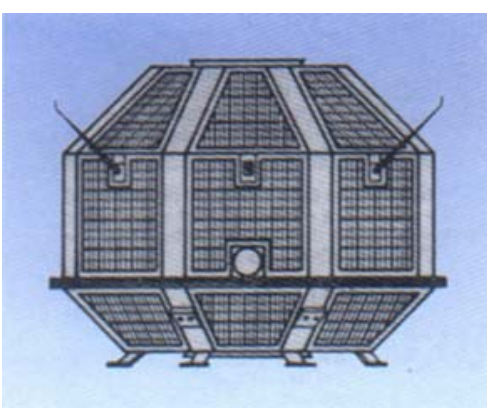

Fig. 4. Space satellite Aryabhata (source: Rakety i kosmicheskie apparaty Konstruktorskogo bureo "Yuzhnoe», ed. by S.N. Konjuhov, $2^{\text {nd }}$ ed., Dnepropetrovsk 2004).

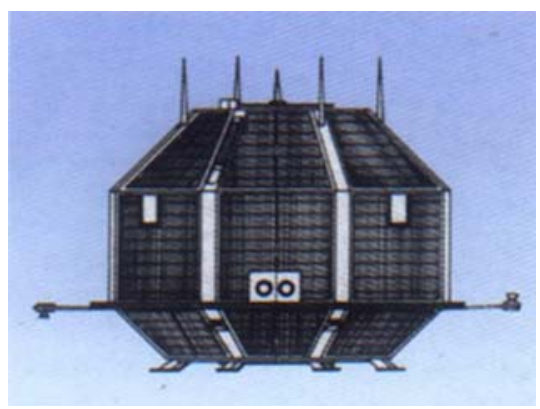

Fig. 5. Space satellite Bhaskara (source: Rakety i kosmicheskie apparaty Konstruktorskogo bureo «Yuzhnoe», ed. by S.N. Konjuhov, $2^{\text {nd }}$ ed., Dnepropetrovsk 2004).

Pre-launch processing of the spacecraft at the cosmodrome involved the installation of research instrumentation, its verification in nominal operating conditions in flight, and electromagnetic compatibility of the entire spacecraft hardware complex. Kovtunenko, Ivan Lysenko, Anatoly Popel, and Boris Khmyrov were the technical managers of the work. The Chairman of the State Commission was the SRI deputy director, George Narimanov. It should be noted that officers, soldiers, industry representatives, cosmodrome commanders also did a great job of preparing spacecraft and launch vehicle launches. ${ }^{84}$

The scientific, public, and government circles in India highly praised the assistance of the Soviet side, including the staff of KB Yuzhnoye. In particular, professor Rao (co-director of the satellite launch project), answering a question about the role of the first Indian satellite Aryabhata, noted that:

India is a developing country. Space allows us to raise not only the level of science and technology but also solve a number of problems that are vital for the country. Having made the first satellite, we can create another. ${ }^{85}$

The exposition dedicated to the first satellites of India - Aryabhat and Bhaskara - is now located in the city of Bangalore in the Visvesvaraya Industrial and Technological Museum, in the Hall of Space.

In 1980, with the launch of its satellite using its own launch vehicle, India became the seventh space power. Four years later, in 1984, the first Indian cosmonaut, Rakesh Sharma, under the Interkosmos program, flew on the Soyuz-T-11 Soviet spacecraft and visited the Salyut-7 space station. After spending 7 days, 21 hours, and 41 minutes in space, on 11 April 1984, the expedition returned to Earth. At the same time, the Soyuz T-10 spacecraft was used for landing.

The Soviet-Indian crew conducted scientific research in three areas: space medicine, space materials science, and remote sensing of the Earth. Table 2 lists only the experiments and studies conducted with the participation of the Indian cosmonaut. 
Table 2. Experimental programs of the Soviet-Indian crew

\begin{tabular}{|c|c|c|c|}
\hline No & Date & $\begin{array}{c}\text { Name of the research } \\
\text { experiment }\end{array}$ & Purpose \\
\hline \multirow[t]{4}{*}{1} & 04.04 .1984 & 'Questionnaire' & \\
\hline & \multirow[t]{3}{*}{05.04 .1984} & 'Optokinesis' & $\begin{array}{l}\text { Study of the oculomotoricity and charac- } \\
\text { teristics of the vestibular and visual interac- } \\
\text { tion; assessment of the state of vestibular } \\
\text { function after the impact of strictly dosed } \\
\text { stimuli }\end{array}$ \\
\hline & & 'Prevention' & $\begin{array}{l}\text { Evaluation of the effectiveness of preven- } \\
\text { tive measures that reduce the adverse ef- } \\
\text { fects of space flight factors on humans }\end{array}$ \\
\hline & & $\begin{array}{l}\text { 'Yoga' (conducted } \\
\text { daily) }\end{array}$ & $\begin{array}{l}\text { Capability and effectiveness of practicing spe- } \\
\text { cial exercises to prevent the adverse effects } \\
\text { of weightlessness }\end{array}$ \\
\hline \multirow[t]{4}{*}{2} & \multirow[t]{4}{*}{06.04 .1984} & $\begin{array}{l}\text { 'Terra' (remote sensing } \\
\text { experiment) }\end{array}$ & $\begin{array}{l}\text { Mapping, study and cataloguing of natu- } \\
\text { ral resources of India for developing its } \\
\text { economy }\end{array}$ \\
\hline & & $\begin{array}{l}\text { Medical experiment } \\
\text { 'Ballisto-3' }\end{array}$ & $\begin{array}{l}\text { Assessment and prediction of the function- } \\
\text { al state of the human cardiovascular system } \\
\text { in space flight }\end{array}$ \\
\hline & & 'Vector' & $\begin{array}{l}\text { Study of the bioelectric activity of the heart, } \\
\text { the phase structure of the cardiac cycle, } \\
\text { assessing the compensatory-adaptive reac- } \\
\text { tions of the circulatory system }\end{array}$ \\
\hline & & 'Poll' & $\begin{array}{l}\text { Self-rating of mood by twelve signs charac- } \\
\text { terizing the emotional state }\end{array}$ \\
\hline \multirow[t]{3}{*}{3} & \multirow[t]{3}{*}{ 07.04.1984 } & 'Terra' & Continuation of the experiment \\
\hline & & 'Questionnaire' & Continuation of the experiment \\
\hline & & 'Poll' & Continuation of the experiment \\
\hline \multirow[t]{4}{*}{4} & \multirow[t]{4}{*}{ 08.04.1984 } & $\begin{array}{l}\text { Medical experiment } \\
\text { 'Ballisto-3' }\end{array}$ & Continuation of the experiment \\
\hline & & 'Optokinesis' & Continuation of the experiment \\
\hline & & 'Terra' & Continuation of the experiment \\
\hline & & ‘Questionnaire' & Continuation of the experiment \\
\hline \multirow[t]{4}{*}{5} & \multirow[t]{4}{*}{ 09.04.1984 } & $\begin{array}{l}\text { Medical experiment } \\
\text { 'Ballisto-3' }\end{array}$ & Continuation of the experiment \\
\hline & & 'Optokinesis' & Continuation of the experiment \\
\hline & & 'Terra' & Continuation of the experiment \\
\hline & & 'Questionnaire' & Continuation of the experiment \\
\hline \multirow[t]{2}{*}{6} & \multirow[t]{2}{*}{ 10.04.1984 } & 'Terra' & Continuation of the experiment \\
\hline & & 'Poll' & Continuation of the experiment \\
\hline
\end{tabular}

Compiled by the authors from the sources.$^{86}$ The table shows the experiments with the participation of the Indian cosmonaut. 
The significance of the experiments and studies carried out in India is indicated, for example, by the fact noted in the book Kosmicheskoe sodruzhestvo (Space Commonwealth):

Surveying the territory of India from the Salyut-7 station using only the MKF-6M camera for five minutes allows you to get as many images as aerial photography can give in two years of continuous operation. ${ }^{87}$

A similar multi-zone survey of areas of North India, conducted by cosmonaut-researcher Rakesh Sharma, was used to determine, for example, the possibility of building a hydroelectric power station in the Himalayas.

In 2017, an article in one of the journals published in Russia rightly stated:

It is noteworthy that Soviet specialists assisted their Indian colleagues not only in choosing the optimal design of the spacecraft. They also participated in ground development testing of the satellite, provided the necessary assistance in the initial phase of controlling the spacecraft in orbit. ${ }^{88}$

Although this article is pretentiously titled Russian components of the Indian space, all this was done with the direct and active participation of the Dnepropetrovsk Space and Rocket Center (Ukraine) in the collective actions at all levels of the Interkosmos program.

Modern Indian historians highly appreciate the Soviet-Indian cooperation in the study of cosmos. An article by the Indian historian Hrushikesh Dalavi, for example, notes that space cooperation and contacts in this area between the Soviet Union and India began in the 1960s and 'for over four decades [...] there has been a relationship of mutual trust and confidence. There were three main areas of cooperation: launchers, navigation and science, reconnaissance. ${ }^{89}$

\section{Results of international cooperation within the Interkosmos program}

In the 1960s and 1980s, scientists from ten socialist countries implemented large-scale space projects and experiments under the Interkosmos program that were aimed at soIving the most pressing problems in the field of space exploration.

In total, within the framework of the program, from October 1969 to December 1991, 25 Interkosmos satellites were launched for joint research, two of which - InterkosmosKopernik-500 (launched in 1973) and Interkosmos-Bulgaria-1300 (started in 1981) - were launched under bilateral Soviet-Polish and Soviet-Bulgarian programs. The last launch of the automatic spacecraft - Interkosmos-25 (AUOS-Z-AP-IK) was carried out on 18 December 1991 from the Plesetsk cosmodrome. ${ }^{90}$

87 V.A. Alekseev, A.A. Eremenko, A.V. Tkachev, op. cit.

88 V. Ivashin, Rossijskie komponenty indijskogo kosmosa, "Indijskij vestnik. Bjulleten' posol'stva Indii v Rossii" April 2017, p. 5.

89 H. Dalavi, History of Indo-Russian Space Cooperation: a Symbiosis of Strategic and Economic Security, www. academia.edu/37441607/ [accessed 17.01.2020].

90 «Intercosmosu - 50», p. 3. 
Table 3, extracted from Gazenko's article, ${ }^{91}$ shows statistical data reflecting the structure and quantitative composition of space objects launched under the Interkosmos program from 1968 to 1990 (excluding meteorological rockets and high-altitude balloons).

Table 3. Space research objects launched into space in the USSR (1968-1990)

\begin{tabular}{|l|c|}
\hline \multicolumn{1}{|c|}{ Space objects } & Number of launches \\
\hline Rocket probes Vertikal & 11 \\
\hline Artificial Earth satellites: & 25 \\
\hline - Interkosmos series & 9 \\
\hline - Prognoz & 28 \\
\hline - biosatellites, Meteor, Meteor-Priroda, Magnon, Molniya & 8 \\
\hline Automatic interplanetary stations (Luna, Venera, Vega, etc.) & 12 \\
\hline Manned spacecraft Soyuz, OS (Salute, Mir) & \\
\hline
\end{tabular}

Source: .G. Gazenko, Programma 'Interkosmos'. Kratkij istoricheskij ocherk, [in:] Materialy Mezhdunarodnoj nauchnoj konferencii 'Interkosmos-30', 9-10.04.2001, Moscow 2003, p. 14-22.

There is one more important aspect of cooperation under the Interkosmos program. According to the participants of the program, trips to working sessions were 'a window to the world', and they made it possible to learn how their foreign colleagues lived and worked. The trips allowed them to enlarge their cultural perspectives and see, e.g. Budapest, Berlin, Prague, Warsaw, Varna, or Dresden, and to visit museums and theaters there, which was a rare opportunity for a Soviet person at that time. In India, Soviet specialists attended interesting cultural programs, got acquainted with Indian cinema, and met an outstanding artist and thinker Svetoslav Roerich, who lived in his estate near Bangalore. ${ }^{92}$

The results of the Interkosmos program were summed up at the international conference Interkosmos-30, held in Moscow in 2001. In his closing remarks, academician Vladimir Kotelnikov (head of the program since 1980) evaluated the results as follows:

The program helped us receive unique scientific results of the study of the Universe, the phenomena that occur in zero gravity. A whole series of space technologies were created, as well as spacecraft and space-based research equipment which needed to be small, lightweight and highly reliable, since they had to work in conditions when there was no service available. Scientific teams, formed in many countries, mastered these new areas of research and technology, successfully worked and keep working in the field of space investigation. ${ }^{93}$

Scientists needed many years to realize that space exploration is the matter of all mankind; that efforts of only one country, albeit a powerful one, are not enough to conduct full-scale research in this area. The prospects for the development of international cooperation in exploration and use of outer space for peaceful purposes are vast and diverse. 
The Interkosmos program, implemented in the $20^{\text {th }}$ century, was the first successful example of broad cooperation in the space industry, which brought significant results. ${ }^{94}$

\section{Conclusions}

In the 1960s, based on military rocketry, KB Yuzhnoye developed a complex of unmanned spacecraft to implement the first international program for peaceful exploration and use of outer space (Interkosmos). For the first time in world history, the R-12 (SS-4) missile was used as a launch vehicle capable of delivering scientific spacecraft into space. Its application marked the beginning of conversion in space rocket technology. A distinctive feature of the space rocket complex, created on the basis of the R-12 combat missile, was that the launch vehicle had a second stage.

The peaceful exploration of Space in OKB-586 started at the time of enormous engagement of the team in the production of the latest military equipment: strategic combat missiles. Turning the attention of highly qualified specialists to a new focus area raised concerns that affected the opinion of many OKB-586 managers. Awareness of the need for a new field of investigation and its sufficiently resonant success removed the objections and led (with the support of Yangel) to the expansion of the activities leading to the creation of new type launch vehicles and spacecraft and establishing of a special bureau for spacecraft in the structure of OKB-586 (Yuzhnoye Design Bureau). Kovtunenko, deputy chief designer of KB Yuzhnoye, played a crucial role in organizing the activities of the spacecraft bureau.

Design and exploration work on space-related topics at Yuzhnoye made it possible to find many innovative solutions to complex scientific and technical problems and design tasks associated with the creation of unmanned spacecraft for scientific research.

For the first time, the idea of creating a 'unified spacecraft', that is, space-based platforms at which it was possible to install diverse instrumentation in order to solve an array of scientific problems, was realized. The experience of the unified spacecraft creation is used at Yuzhnoye SDO named after Yangel till this day.

The work on the use and conversion of combat missiles into launch vehicles for artificial Earth satellites and the implementation of the idea of space platforms made a solid foundation for the success of the international scientific Interkosmos project. The experiments conducted on the Interkosmos series satellites, created at the Dnepropetrovsk Rocket and Space Center, yielded unique scientific results in the fields of solar physics, the upper atmosphere, the Earth's ionosphere and magnetosphere, as well as cosmic rays, short-wave and burst radiation waves of the Sun, auroras, etc. The global assessment of the research results was high. The data obtained were used for the development of many branches of science; a significant contribution was made to the improvement of space exploration technologies.

The launch vehicles and spacecraft, created in OKB-586 for solving fundamental scientific problems and applied problems in the field of remote sensing of the Earth, opened 
up new possibilities for their peaceful use. The results of cooperation under the Interkosmos program between the countries such as, e.g. Poland and India confirm this conclusion. The activities of all structures (including Yuzhnoye) for technical support of scientific research in space within the framework of the Interkosmos program for the first time in world history clearly emphasized the unlimited possibilities for solving the global problems of mankind that the transition from military confrontation to peaceful international cooperation provides.

The practice of international cooperation in space research, launched by the Interkosmos program, is widely used in the $21^{\text {st }}$ century to organize joint research and experiments conducted by the USA and the European Space Agency.

\section{Bibliography}

\section{Archival sources}

Central State Archive of Public Organizations of Ukraine, Harakteristika dejatel'nosti Juzhnogo mashinostroitel'nogo zavoda i Konstruktorskogo bjuro «Juzhnoe» (1944-1967 gg.) ss., f.1, op. 24 , d. 6340, p. 1-16.

Archive of the Presidium of the NAS of Ukraine, Lichnoe delo akademika Budnika V.S., op. 646,46 p.

State Archive of the Russian Federation, Postanovlenie Soveta Ministrov SSSR no 1017419 ss ot 13 maja $1946 \mathrm{~g}$ «Voprosy reaktivnogo vooruzhenija», Podlinnik. Avtograf I.V. Stalina, f. R-5446, op. 3as, d. 23, I. 216.

Popel' A.M., an interview with O.A. Gubka, 2007, (authors' archive).

\section{Published sources}

Budnik V.S., Ot shturmovikov IL-2 do kosmicheskih raket (vospominanija), Dnepropetrovsk 1993.

Dogovor o principah dejatel'nosti gosudarstv po issledovaniju i ispol'zovaniju kosmicheskogo prostranstva, vkljuchaja Lunu I drugie nebesnye tela, [in:] Dogovory i principy Organizacii Ob'edinennyh Nacij, kasajushhiesja kosmicheskogo prostranstva, sootvetstvujushhie rezolucii General'noj Assamblei i drugie document, Vienna 2013, p. 3-8.

Gubarev V., Besedy s akademikom Vladimirom Utkinym. Chast' poslednjaja, www.pravda.ru/science/909597-esedy_s_akademikom_vladimirom_utkinym_chast_poslednja$\mathrm{ja}$ / [accessed 02.02.2020].

«Interkosmosu - 50», "Konstruktor" 15.10.2019, no 21 (1048).

Kocmicheskij apparat Interkosmos-9 (Kopernik-500), stp.cosmos.ru/index.php?i$d=1163 \&$ tx_ttnews\%5Btt_news\%5D =2979\&cHash=ac034cfa43653e86efc227b7d2a060ac [accessed 29.01.2020].

Kotel'nikov V.A., Sud'ba ohvativshaja vek, vol. 2, ed. by. A.S. Prohorov, Moscow 2011. Materialy soveshhanija jexpertov-predstavitelej socialisticheskih stran po issledovaniju i ispol'zovaniju kosmicheskogo prostranstva v mirnyh celjah, Moscow 1967.

Nowacki W., S emblemoj Interkosmosa, "Pravda" 29.06.1978.

Rakety i kosmicheskie apparaty Konstruktorskogo bureo "Yuzhnoe», ed. by S.N. Konjuhov, $2^{\text {nd }}$ ed., Dnepropetrovsk 2004. 
Rakety i kosmicheskie apparaty Konstruktorskogo bureo «Yuzhnoe», ed. by S.N. Konjuhov. $3^{\text {rd }}$ ed., Kiev 2004.

"Vas zhdut na Orbite!», "Konstruktor" 14. 11. 2019, no 23 (1050), p. 2-3.

Zadacha osoboi gosudarstvennoi vazhnosti. Iz istorii sozdaniia raketno-iadernogo oruzhiia i Raketnykh voisk strategicheskogo naznacheniia (1945-1959 gg.): sbornik dokumentov, Moscow 2010.

\section{Critical literature}

Alekseev V.A., Eremenko A.A., Tkachev A.V., Kosmicheskoe sodruzhestvo: hronika mezhdunarodnyh poletoved, ed. by A.S. Eliseev, Moscow 1987.

Burgess C., Vis B., Interkosmos: The Eastern Bloc's Early Space Program, Cham, Heildeberg 2016, DOI 10.10007/978-3-319-24163-0_4.

Chaplic O.A., Sanin F.P., Programma «Interkosmos» $i$ ee vklad v razvitie mirovoj kosmonavtiki, „Visnik Dnipropetrovs'kogo universitetu. Serija Istorija i filosofija nauki i tehniki” vol. 18, 2010, no 18, p. 65-71.

Dalavi H., History of Indo-Russian Space Cooperation: a Symbiosis of Strategic and Economic Security, www.academia.edu/37441607/ [accessed 17.01.2020].

Degtiarev A.V., 50 let na kosmicheskikh orbitakh, "Kosmicheskaia nauka i tekhnologiia" vol. 18, 2012, no 2, p. 59-80.

Gałązka R.R., Trzydzieści sześć lat działalności człowieka w Kosmosie, "Urania” vol. 65, 1994, no 1, p. 2-7.

Gouarné, I. Dépasser les tensions Est-Ouest pour la conquête de l'espace. La coopération franco-soviétique au temps de la guerre froide, "Les Cahiers Sirice" 2016, no 16, p. 49-67.

Gorbulin V.P., Koltachihina O.Ju., Hramov Ju.A., Osnovnye periody i jetapy razvitija raketno-kosmicheskoj tehnyki Ukrainy. Ch. 2. Sozdanie boevyh strategicheskih ballisticheskih raket i raketnyh kompleksov (1957-1900), "Nauka ta naukoznavstvo" 2014, no 2 (84), p. 77-103.

Gubarev V.S. Ariabata, Moscow 1975.

Hanasz J., Aksenov V.I., Komrakov G.P. First results of the Soviet-Polish space experiment 'Intercosmos-Kopernik 500', [in:] Exploration of the Planetary System, ed. by A. Woszczyk, C. Iwaniszewska, Dordrecht 1974, p. 67-73, DOI 10.1007/978-94-010-22064 . 7 .

Harvey B., Zakutnyaya O., Russian Space Probes: Scientific Discoveries and Future Missions, Dordrecht 2011.

Ivashin V., Rossijskie komponenty indijskogo kosmosa, "Indijskij vestnik. Bjulleten' posoI"stva Indii v Rossii" April 2017, p. 4-7.

Kavelin S. S., Glavnoe delo zhizni, "Kosmichna nauka i tehnologija" vol. 2, 1996, no 3-4, p. 102-103.

Konyuhov S.N., Uchenyj, tvorec, jentuziast, "Technicheskaja mehanika"2001, no 1, p. 181 184.

Kozyrev V.I., Nikitin S.A., Polety po programme 'Interkosmos', Moscow 1980.

Materialy Mezhdunarodnoj nauchnoj konferencii 'Interkosmos-30', 9-10.04.2001, ed. by V.A. Kotel'nikov, Moscow 2003.

Nehamkin I., Denisenko V., USSR-India. Put' k zvezdam, Moscow 1984. 
O programme 'Interkosmos', www.astronaut.ru/as_interk/as_interk.htm [accessed 01.02.2020].

Petrov B.N., Programma 'Interkosmos'. Sotrudnichestvo socialistycheskih stran, scifiart. narod.ru/Albums/4_004.htm [accessed 17.01.2020].

Platonov V.P., Planeta Kovtunenko, "Zerkalo nedeli" 2005, no 13 (541), p. 13.

Prizvany vremenem. Ot protivostojanija $k$ mezhdunarodnomu sotrudnichestvu, ed. by

S.N. Konjuhov, Dnepropetrovsk 2009.

Remek V., Astronaut on CSSR-USSR cooperation in Intercosmos Program, "Rude Pravo" 28 May 1982, [in:] East Europe Report. Scientific Affairs, "JPRS" 10.08.1982, no 751, p. $1-5$.

Ryhlova R.V., Pervye opticheskie nabludenija iskusstvennyh sputnikov Zemli: kak jeto bylo. Materialy doklada, predstavlennogo 27 sentjabrya 2007 goda na yubilejnom nauchno-tehnicheskom seminare "Problemy obnaruzhenija i soprovozhdenija kosmicheskih ob'ektov v okolozemnom kosmicheskom prostranstve", Ifvn.astronomer.ru/ report/0000036/ [accessed 02.02.2020].

Sanin F.P., Chaplic O.A., Kovtunenko - vydajushhijsja uchenyj, sozdatel' pervyh ukrainskih sputnikov, "Visnik Dnipropetrovs'kogo universitetu. Serija Istorija i filosofija nauki i tehniki" vol. 20, 2012, p. 223-227.

Sanin F.P., Chaplic O.A., V.M. Kovtunenko: period raboty v KB 'Yuzhnoe' im. M.K. Jangelja, "Visnik Dnipropetrovs'kogo universitetu. Serija Istorija i filosofija nauki i tehniki" vol. 19, 2011, no 19, p. 3-7.

Savchuk V.S., V.S. Budnik ta jogo naukovo-konstruktors'ka shkola, "Nauka ta naukoznavstvo" 2013, no 3, p. 89-101.

Savchuk V.S., Sanin F.P., Yacenko V.Ja., Kavun M.E., Portnov A.V., 'Secretnij' pidrozd I galuz, ed. by M.V. Poljakov, Dnepropetrovsk 2001.

Serova L.V., 'Interkosmos' v jeksperimentah na biosputnikah, "Kosmicheskij al'manah" 2001, no 5, epizodsspace.narod.ru/bibl/akiem/5-inter.html_[accessed 29.01.2020].

Sylwester J., Experience of Wroclaw Team in Construction of Solar X-ray Instruments, [in:] ESA, vol. 493, 2001, p. 377-382.

The Interkosmos space program, Space Legal Issues, www.spacelegalissues.com/spacelaw-interkosmos/ [accessed 02.02.2020].

Vedeshin L.A., K 50-letiju poleta sputnika 'INTERKOSMOS-1', "Issledovanie Zemli iz Kosmosa" 2019, no 4, p. 87-93.

Vedeshin L.A., Kroshkin M.G., Sputnik 'Interkosmos-1' i ego nauchnaja programma (sotrudnichestvo uchenyh socialisticheskih stran v issledovanii kosmosa, "Vestnik Akademii nauk SSSR" 1969, no 12, p. 19-27.

Wolczek O., Poland in the Intercosmos program, "Spaceflight" vol. 22, 1980, no 5, p. 190-192.

Ol'ga Gubka, engineer, M.K. Yangel Yuzhnoye State Design Office e-mail: olyachaplits@gmail.com

Varfolomii Savchuk, Doctor of History Sciences, Tenured Professor, Oles Honchar Dnipro National University, Dnipro, Ukraine.

e-mail: varfolomey44@gmail.com 
Article submitted on 6 December 2019

Article accepted on 13 March 2020

Dniepropietrowski Ośrodek Kosmiczny: od rakiet balistycznych do międzynarodowej współpracy w ramach programu Interkosmos

Międzynarodowy projekt badań kosmicznych Interkosmos składał się z wielu elementów; w jego funkcjonowaniu można wyodrębnić różne aspekty: polityczny, naukowy, ekonomiczny, propagandowy, techniczny etc. W artykule autorzy przedstawiają techniczny wykład Dniepropietrowskiego Ośrodka Kosmiczno-Rakietowego w program Interkosmos. Artykuł omawia techniczne zagadnienia przekształcenia produkowanych w Ośrodku rakiet wojskowych do wykorzystania w eksploracji kosmosu. Autorzy, opierając się na wspomnieniach uczestników tych wydarzeń, opisują mało znane aspekty utworzenia prężnych zakładów produkujących satelity w Dniepropietrowskim Ośrodku Kosmiczno-Rakietowym. Artykuł podkreśla znaczenie rozwijanej w Biurze Projektowym Jużnoje idei stworzenia „zunifikowanego statku kosmicznego” - podstawy konstrukcyjnej, na której można by instalować różne instrumenty do rozwiązywania szerokiego wachlarza problemów badawczych. Na przykładzie Polski i Indii zostały przedstawione wyniki, które uzyskano podczas bezzałogowych i załogowych misji kosmicznych w ramach programu Interkosmos z zaznaczeniem udziału tych krajów w opracowaniu instrumentów naukowych służących programowi oraz znaczenie tego kierunku badań i rozwoju. 